Biografistyka Pedagogiczna

Rok 1 (2016) nr 1

ISSN 2543-6112; e-ISSN 2543-7399

DOI: 10.36578/BP.2016.01.17

Katarzyna Sabat*

\title{
Prośba o ułaskawienie źródłem do biografii Żołnierzy Wyklętych
}

\section{A Request for Clemency as a Source for the Biographies of Cursed Soldiers}

Termin „Żołnierze Wyklęci” coraz częściej jest używany przez społeczeństwo polskie. Pojęcie to pojawia się bowiem w przestrzeni publicznej, historiografii, a także publicystyce. Po raz pierwszy zostało użyte w 1993 r. przez zwolenników Ligi Republikańskiej, którzy zorganizowali na Uniwersytecie Warszawskim wystawę pt.: Żołnierze Wyklęci - antykomunistyczne podziemie zbrojne po 1944 roku¹. Jednakże termin: „wyklęci” zaczął rozpowszechniać się dopiero po ukazaniu się książki Jana Ślaskiego pod tytułem Żołnierze wyklęci ${ }^{2}$ w 1996 r. Choć publikacja Ślaskiego nie była monografią naukową, to stanowiła pierwszą próbę przedstawienia losów osób zaangażowanych w powojenną walkę o niepodległość państwa polskiego ${ }^{3}$. Sejm Rzeczypospolitej Polskiej ustawą z 3 lutego $2011 \mathrm{r}$. uchwalił 1 marca Narodowym Dniem Pamięci Żołnierzy Wyklętych ${ }^{4}$. Święto zostało ustaniowione w hołdzie „bohaterom antykomunistycznego podziemia, którzy w obronie niepodległego bytu Państwa Polskiego, walcząc o prawo do samostanowienia i urzeczywistnienie dążeń demokratycznych społeczeństwa polskiego, z bronią w ręku, jak i w inny sposób, przeciwstawili się sowieckiej agresji i narzuconemu siłą reżimowi komunistycznemu" ${ }^{\prime \prime}$.

* Katarzyna Sabat - mgr, doktorantka w Instytucie Pedagogiki Katolickiego Uniwersytetu Lubelskiego Jana Pawła II, sabat128@vp.pl.

1 M. Solecki, Literackie portrety żołnierzy wyklętych, Łomianki 2013, s. 9.

2 J. Ślaski, Żołnierze wyklęci, Warszawa 1996.

3 S. Nowak, Oddziały wyklętych, Warszawa 2014, s. 22.

4 Ustawa dnia 3 lutego 2011 r. o ustanowieniu Narodowego Dnia Pamięci „Żołnierzy Wyklętych”, Dz.U. 2011, nr 32, poz. 160.

5 Tamże. 
Żołnierze Wyklęci, podejmujący czyn zbrojny przeciwko komunistycznej władzy i sowietyzacji kraju, działali w latach 1944-1963 ${ }^{6}$. Szacuje się, iż w 1945 r. zostało utworzonych 350 oddziałów podziemia niepodległościowego na terenie ówczesnej Polski, w szeregach których walczyło od 13 tys. do 17 tys. żołnierzy. Ponad połowa z nich należała do struktur Armii Krajowej (AK) przekształconej w Delegaturę Sił Zbrojnych na Kraj (DSz), a następnie w Ruch Oporu bez Wojny i Dywersji „Wolność i Niezawisłość” (WiN). Inna część żołnierzy była skupiona w szeregach oddziałów o proweniencji narodowej, były to m.in.: Narodowa Organizacja Wojskowa (NOW), Narodowe Siły Zbrojne (NSZ) i Narodowe Zjednoczenie Wojskowe (NZW). Istniały także organizacje niepodporządkowane żadnemu zwierzchnictwu, do których należały regionalne lub samodzielne oddziały zbrojne liczące od 3700 do 4800 żołnierzy ${ }^{7}$.

Wokół polskiego podziemia antykomunistycznego narosło wiele sprzecznych i nieprawdziwych informacji. Przyczyną takiego stanu rzeczy była dobrze zorganizowana i prężnie działająca komunistyczna propaganda. Do końca lat osiemdziesiątych XX w. bohaterów walk o wolną Polskę nazywano najczęściej: bandytami, faszystami, reakcjonistami, zdrajcami, sprzedawczykami oraz zaplutymi karłami reakcji ${ }^{8}$. Reakcyjnym bandytą - w rozumieniu komunistycznych władz - był każdy członek należący do polskich struktur podziemia niepodległościowego uczestniczący w nowej konspiracji powojennej bądź ten, którego działalność nie zakończyła się wraz z okupacją niemieckąa9.

6 D. P. Kucharski, Wierni niepodległej, w: Do końca wierni. Żołnierze wyklęci 1944-1963, red. D. P. Kucharski, R. Sierchuła, Poznań 2014, s. 22.

7 Zaplute karty reakcji. Polskie podziemie niepodległościowe 1944-1956, red. A. Jaczyńska, M. Śladecka S. Poleszak, R. Wnuk, Lublin 2013, s. 9-10.

8 Symbolem agresywnej propagandy komunistycznej oraz rozprawy władzy komunistycznej z Armią Krajową stał się plakat autorstwa W. Zakrzewskiego Olbrzym i zapluty karzet reakcji.

9 T. Łabuszewski, Bandy reakcyjnego podziemia czy zbrojne podziemie niepodległościowe, http://klub-generalagrota.pl/kg/baza-wiedzy/referaty/639,Bandy-reakcyjnego-podziemia-czy-zbrojne-podziem ie-niepodleglosciowe.html, dostęp: 21.09.2016.

10 K. Szwagrzyk,Aparat bezpieczeństwa w latach 1944-1956, w: Aparat bezpieczeństwa w Polsce. Kadra Kierownicza 1944-1956, red. K. Szwagrzyk, t. 1, Warszawa 2005, s. 25.

11 T. Łabuszewski, Wstęp, w: Śladami zbrodni. Przewodnik po miejscach represji komunistycznych lat 19441956, red. T. Łabuszewski, Warszawa 2013, s. 7.
Walcząc z nowym ustrojem władzy komunistycznej, polscy żołnierze podziemia niepodległościowego mogli polegać wyłącznie na sobie. W latach 1944-1956 wskutek terroru zastosowanego przez aparat bezpieczeństwa wyniszczono elity II Rzeczypospolitej oraz rozbito zbrojne i polityczne podziemie niepodległościowe ${ }^{10}$. Dotychczas nie udało się ustalić - w sposób naukowy - szczegółowej statystyki ofiar zbrodni popełnionych przez terenowe organy bezpieczeństwa publicznego, wojskowo-policyjne grupy pacyfikacyjne czy sowieckie struktury Ludowego Komisariatu Spraw Wewnętrznych (NKWD) i Ludowego Komisariatu Bezpieczeństwa Państwowego ZSRR (NKGB) ${ }^{11}$. Pozostają tylko 
dane orientacyjne, wynika z nich, iż aresztowano blisko 79 tys. osób, wśród których 21 tys. osób zmarło w palcówkach penitencjarnych, na karę śmierci skazano 5 tys. osób ${ }^{12}$, z czego ponad 3 tys. wyroków zostało wykonanych ${ }^{13}$.

Wojskowy Sąd Rejonowy (WSR) w Rzeszowie w latach 1946-1955 skazał na karę śmierci - za działalność na rzecz niepodległego państwa polskiego - 122 osoby. Dwudziestu z nich zostało straconych, pięciu zmarło przed zakończeniem odbywania kary więzienia, a trzydziestu ośmiu otrzymało cząstkową karę śmierci. Sześćdziesiąt cztery osoby otrzymały złagodzony wyrok śmierci, który zmieniony został na dożywocie lub wieloletnie więzienie poprzez zastosowanie przepisów o amnestii bądź aktu łaski Prezydenta Krajowej Rady Narodowej (KRN), a od 1947 r. Prezydenta $\mathrm{RP}$ - Bolesława Bieruta ${ }^{14}$. Inaczej przedstawia się obraz wymiaru sprawiedliwości WSR w Krakowie, który w tych samych latach orzekł karę śmierci w 212 sprawach i w 397 przypadkach skazał na nią 392 osoby. Powyższa statystyka jest skutkiem łączenia spraw sądowych, w których w jednym wyroku na karę śmierci skazano więcej niż jedną osobę $e^{15}$.

Do takich spraw grupowych z pewnością należy zaliczyć pierwszą rozprawę pokazową przeciwko żołnierzom należącym do struktur Pogotowia Akcji Specjalnej NZW (PAS NZW) i członkom wiN działającym w Tarnowskiem. Na ławie oskarżonych zasiadły 22 osoby $^{16}$, wśród których znajdowali się członkowie Brygady Wywiadowczej (BW), WiN, a także konspiratorzy niepodległościowi pod dowództwem Tadeusza Gajdy ps. „Tar$\operatorname{zan}^{\prime \prime 17}$. Należy nadmienić, iż fundamentalna działalność niepodległościowa Gajdy związana była z północnym

12 S. Nowak, Oddziały wyklętych, s. 22.

13 T. Łabuszewski, Wstęp, s. 7.

14 T. Bereza, Program badawczy IPN „Osoby skazane na kare śmierci przez wojskowe sądy rejonowe w latach 1946-1955", w: Skazani na karęśmierci przez Wojskowy Sąd Rejonowy w Rzeszowie 1944-1954, red. T. Bereza, P. Chmielowiec, Rzeszów 2004, s. 7.

15 F. Musiał, Polityka czy sprawiedliwość? Wojskowy Sąd Rejonowy w Krakowie (1946-1955), Kraków 2005, s. 368-369.

16 Archiwum Instytutu Pamięci Narodowej w Krakowie (dalej: AIPN Kr), sygn. 110/450/4, Akt oskarżenia, 13 października 1946, k. 13-31.

17 Tadeusz Gajda „Tarzan” (1924-1946) - od 1941 r. należał do struktur NOW, od 1943 r. członek oddziału NOW-AK Franciszka Przysiężniaka „Ojca Jana”. W 1944 r., podczas okupacji niemieckiej, brał udział w bitwie partyzanckiej na Porytowym Wzgórzu. W październiku 1944 r. wstąpił w szeregi 25. Pułku 19. Dywizji Piechoty Armii Berlinga, skąd kilka miesięcy później zdezerterował. W 1945 r. został dowódcą oddziału partyzanckiego w Okręgu Rzeszowskim NZW, a w marcu 1946 r. szefem Pogotowia Akcji Specjalnej przy Inspektoracie „Tatar”. 7 sierpnia $1946 \mathrm{r}$. został aresztowany przez funkcjonariuszy UB w Tarnowie. Wyrokiem WSR w Krakowie z dnia 27 września 1946 r. skazano go na karę śmierci, wyrok wykonano 14 października 1946 r. w Centralnym Więzieniu Montelupich w Krakowie. Archiwum Instytutu Pamięci Narodowej w Rzeszowie (dalej: AIPN Rz), sygn. 0172/4/J, Charakterystyka nr 6-c bandy Narodowej Organizacji Wojskowej pod dowództwem Gajdy Tadeusza ps. „Tarzan". Charakterystyka dowódcy bandy, 24 czerwca 1985, k. 1-2; B. Szwedo, „Tarzan” i jego żotnierze, „Tarnobrzeskie Zeszyty Historyczne", 13 (1996). 
obszarem powiatu tarnobrzeskiego oraz niżańskiego w ówczesnym województwie rzeszowskim. W 1945 r. utworzył - na jego terenie - oddział, który podlegał Komendantowi Oddziałów Leśnych Okręgu Rzeszów Now (NZw) - Franciszkowi Przysiężniakowi ps. „Ojciec Jan”. Do głównych zadań „Tarzana” i jego żołnierzy należało przeprowadzenie akcji w obronie mieszkańców wsi położonych w północnej części wideł Wisły i Sanu, wymierzanie kary chłosty na gorliwych sprzymierzeńcach „władzy ludowej”, a także akcje ekspropriacyjne związane z koniecznością utrzymania żołnierzy w oddziale. Pod koniec 1945 r. oddział został czasowo rozwiązany, a jego członkowie urlopowani ${ }^{18}$.

Wiosną 1946 r. Gajda otrzymał rozkaz zorganizowania na terenie Tarnowskiego organizacji PAS, która w późniejszym czasie miała zostać włączona w skład Inspek-

18 AIPN Kr, syǵn. 110/450/1, Protokół przesłuchania podejrzanego, 8 sierpnia 1946, k. 13-34; AIPN Rz, sygn. 05/19, Charakterystyka faktologii nr 6-c oddziału Narodowej Organizacji Wojskowej (Now) pod dowództwem: Tadeusz Gajda vel Bernacki ps. „Tarzan", k. 64-283.

19 Zdzisław Furmański ps. „Śmiały” (1927-2013) ur.w Dąbrowie Tarnowskiej, od 1940 r. kolporter pisma podziemnego „Odwet”, od $1943 \mathrm{r}$. uczestnik walk o niepodległą Polskę. W grudniu $1944 \mathrm{r}$. aresztowany przez Niemców, uciekł z transportu do obozu. W maju 1945 r. powrócił do Tarnowa, a miesiąc później zamierzał przedostać się przez Czechosłowację do II Korpusu we Włoszech, ale został aresztowany w Czechowicach-Dziedzicach, do grudnia 1945 r. przetrzymywany był w piwnicach wUBP w Katowicach. W styczniu $1946 \mathrm{r}$. nawiązał kontakt z Władysławem Hajmanem „Jurandem" w celu wspierania NZw w Tarnowie. Udzielił pomocy w zorganizowaniu zakwaterowywania dla członków oddziału „Tarzana”. W sierpniu 1946 r. wyjechał do Szczecina w związku z falą aresztowań. Po przejściu na emeryturę w 1980 r. powrócił do Tarnowa, mieszkał w tym mieście do śmierci. M. Żychowska, Represje komunistyczne w Tarnowskiem 1945-1956, Kraków 2013, s. 256.

20 M. Żychowska, Represje komunistyczne, s. 258.

21 AIPN Kr, sygn. 074/89, Charakterystyka nr 90 reakcyjnej bandy terrorystyczno-rabunkowej pn. Pogotowie Akcji Specjalnej dowodzonej przez Gajdę Tadeusza ps. „Tarzan”, 26 grudnia 1979, k. 5-6.

22 Tamże, k. 7 . toratu „Tatar". W Tarnowie pomocy „Tarzanowi” udzielali: Zdzisław Furmański ps. „Śmiały"19 i Józef Zabdyr ps. „Wydra”. Byli oni jednocześnie odpowiedzialni za organizację kwater dla członków oddziału „Tarzana” pochodzących z powiatu tarnobrzeskiego. Samym przygotowaniem PAS Obwodu Tarnowskiego zajął się Hieronim Stężowski, stając się jego sze$\mathrm{fem}^{20}$. Na tym terenie Oddział przeprowadził kilka akcji, do których można zaliczyć rekwizycję pieniędzy z biura Spółdzielni „Społem” i Izby Skarbowej w Tarnowie, a także wykonanie rozkazu wyroku śmierci na Bogdanie Grzybku ps. „Posępny”, podejrzanym o współpracę z Urzędem Bezpieczeństwa ${ }^{21}$. Należy wziąć pod uwagę, iż Oddział PAS od maja 1946 r. zaczynał się dopiero formować, natomiast w lipcu szef Powiatowego Urzędu Bezpieczeństwa (PUB) w Tarnowie - Stanisław Strzałka - pozyskał do współpracy agenta o pseudonimie „Bezimienny”22, 
którego doniesienia agenturalne w toku współpracy doprowadziły do zlokalizowania miejsca pobytu osób związanych ze strukturami podziemia antykomunistycznego.

Początek aresztowań był związany z członkiem PAS - Wiesławem Budzikiem ps. „Roland”. Do jego aresztowania doszło w podtarnowskiej Łękawicy „w dniu 4 sierpnia 1946 r. w godzinach nocnych. [...] W toku pierwszych przesłuchań przyznał się on, że jest członkiem omawianej bandy, potwierdził posiadane informacje i podał dalszych członków bandy i ich miejsca pobytu”23. „Roland” został poddany brutalnemu śledztwu, podczas którego mężczyznę wieszano za wykręcone do tyłu ręce, stopy polewano benzyną i podpalano ${ }^{24}$. Po wymuszonych zeznaniach Budzika - do połowy sierpnia 1946 r. - aresztowano 21 konspiratorów niepodległościowych, z których najmłodszym był dziewiętnastoletni Ryszard Kwaśniewicz ps. „Łoś”25, zaś najstarszym Andrzej Gardulski mający 63 lata $^{26}$. Aresztowano także Tadeusza Gajdę „Tarzana” ${ }^{27}$. Jego zatrzymanie przez funkcjonariuszy Urzędu Bezpieczeństwa (UB) nastąpiło 7 sierpnia 1946 r., opuszczał on wówczas Park Strzelecki w Tarnowie. „Widział, że jest otoczony. Wyrwał rewolwer i skierował lufę do własnej głowy z zamiarem odebrania sobie życia. Nie zdążył wystrzelić, bo z tyłu kilka rąk chwyciło jego ręce, które wykręcono mu do tyłu i wyrwano broń, następnie wprowadzono go do korytarza małego budynku przy skrzyżowaniu ul. Asnyka i J. Krasickiego, należącego niegdyś do gimnazjum. Tu trzymany z rękami wykręconymi czekał na auto, które przewiozło go na UB"28. Większość aresztowanych była przetrzymywana w piwnicach budynku siedziby UB przy zbiegu ulic Krakowskiej 25 i Malczewskiego $2^{29}$.

Proces sądowy 22 osób trwał od 23 do 27 września 1946 r. przed wSR w Krakowie na sesji wyjazdowej w Tarnowie $^{30}$. Wnioski adwokatów o powołanie dodatkowych świadków mogących mieć korzystne znaczenia dla oskarżonych zostały oddalone przez prokuratora. Przewodniczący składu sądzącego, kpt. mgr Marian Piękosz, był bardzo dobrze zapoznany ze sprawą, a jego nastawienie do osób oskarżonych było nieprzychylne. Pozostałe osoby składu sądzącego nie zadawały żadnych pytań, sprawiając wrażenie

23 Tamże, k. 7.

24 W. Frazik, F. Musiał, Zabić Lwa, w: Precz z komuna. $Z$ archiwów bezpieki - nieznane karty PRL, red. F. Musiał, J. Szarek, t. 3, Kraków 2006, s. 80.

25 AIPN Kr, sygn. 110/450/2, Protokół przesłuchania świadka, 9 sierpnia 1946, k. 5-6.

26 AIPN Kr, sygn. 110/450/2, Protokół przesłuchania świadka, 10 sierpnia 1946, k. 45.

27 AIPN Kr, sygn. 110/450/1, Protokół rewizji osobistej, 7 sierpnia 1946, k. 9.

28 J. Lulek „Wichura”, „Na śmierć wychodzit spokojnie”. Wspomnienia $z$ procesu BW WiN i PAS NZW $w$ Tarnowie, oprac. M. Wenklar, „Zeszyty Historyczne wiN-u”, 30 (2009) s. 129.

29 M. Żychowska, Represje komunistyczne, s. 279.

30 AIPN Kr, sygn. 110/450/4, Protokół rozprawy dnia 23-27 września 1946 r., k. 113-137. 
niezorientowanych i niezainteresowanych przewodem ${ }^{31}$. Wyrokiem wSR w Krakowie z 27 września 1946 r. na karę śmierci skazano siedem osób: Wiesława Budzika, Tadeusza Gajdę, Ryszarda Kwaśniewicza, Kazimierza Orczewskiego, Stanisława Saka, Wojciecha Walla i Józefa Zabdyra. Wobec pozostałych konspiratorów orzeczono karę dożywotniego pozbawienia wolności lub pozbawienia wolności od lat 5 do 15. Tylko dwie osoby zostały uniewinnione ${ }^{32}$. „Po odczytaniu wyroku, sędzia cynicznie oświadczył, że na takie wyroki nie zasłużyliśmy, ale otrzymaliśmy je dla zastraszenia innych [...]. Sędzia oświadczył, że wszystkim skazanym na śmierć sąd wydał pozytywną opinię, z wyjątkiem Gajdy i Budzika. Bo tym już nie mógł. To już oznaczało dla nich pewną śmierć. Do nich należał również Orczewski”33. Wyrok na członkach podziemia antykomunistycznego miał być wykonany niezwłocznie po uprawomocnieniu się. W myślach skazańców pozostawała jednak nadzieja na to, iż pobyt w celi śmierci może zakończyć się ułaskawieniem.

Niewykonanie kary śmierci mogło być spowodowane kilkoma przyczynami, do których należy zaliczyć: cząstkowe kary śmierci, złagodzenie na mocy amnestii, uchylenie lub złagodzenie postanowień Najwyższego Sądu Wojskowego (NSW) oraz złagodze-

31 F. Musiał, Polityka czy sprawiedliwość?, s. 358.

32 AIPN Kr, sygn. 110/45o/4, Wyrok w Imieniu Rzeczypospolitej Polskiej, 27 września 1946, k. 156-171. Wyrokiem WSR w Krakowie z 27 września 1946 roku uniewinniono Andrzeja Gardulskiego i Mieczysława Wciślika.

33 J. Lulek „Wichura”, „Na śmierć wychodził spokojnie”, S. 135.

34 F. Musiał, Skazani na karęśmierci przez Wojskowy Sąd Rejonowy w Krakowie 1946-1955, Kraków 2005, s. 25-27.

35 K. Szwagrzyk, Listy do Bieruta. Prośby o ułaskawienie $z$ lat 1946-1956, Wrocław 1995, s. 6.

36 F. Musiał, Skazani na karę śmierci przez Wojskowy Sąd Rejonowy w Krakowie 1946-1955, s. 25.

37 Decyzją Prezydenta KRN karę śmierci zamieniono R. Kwaśniewiczowi na 15 lat więzienia, AIPN Kr, syğn. 110/450/4, Protokół spisany 28.10.1946 w więzieniu w Krakowie, 28 października 1946, k. 203.

38 Decyzją Prezydenta KRN karęśmierci S. Sakowi śmierci zamieniono na 10 lat więzienia, zob. także, k. 203.

39 Decyzją Prezydenta KRN karę śmierci zamieniono W. Wallowi i J. Zabdyrowi na dożywotnie więzienie, tamże, k. 203. nie przez Bolesława Bieruta bądź Radę Państwa ${ }^{34}$. To osoba skazana zwracała się z prośbą o łaskę, gdyż formalnie miała do tego prawo. Oprócz niej także jej rodzina mogła wnieść prośbę o zmianę wyroku lub darowanie części kary. Trudno jednoznacznie określić, jakie były przyczyny konkretnych decyzji podejmowanych przez Bieruta $^{35}$. Z pewnością większość z nich była podejmowana z uwzględnieniem interesu politycznego. W przypadku WSR w Krakowie Bierut (w tym także Rada Państwa) ułaskawili 76 osób ${ }^{36}$. Wśród nich znaleźli się czterej konspiratorzy z Tarnowskiego, sądzeni wraz z Gajdą. Bierut zastosował prawo łaski wobec Kwaśniewicza ${ }^{37}$, Saka ${ }^{38}$, Walla i Zabdyra ${ }^{39}$. Wobec pozostałych działaczy antykomunistycznego podziemia 
(Wiesława Budzika, Tadeusza Gajdy i Kazimierza Orczewskiego) Prezydent KRN nie skorzystał z prawa łaski ${ }^{40}$.

Prośby o ułaskawienie były konstruowane tak, aby w swym opisie zawierały szeroki wachlarz oczekiwań „Czcigodnego Obywatela Prezydenta”. Krzysztof Szwagrzyk pisze: „prawie wszystkie wypełnione są zwrotami charakterystycznymi dla socjalistycznej »nowomowy«, które w połączeniu z intymnymi niekiedy wyznaniami czynionymi wobec »Ojca Narodu « - tworzą w sumie mieszankę niezwykłą"41. Bierut - w prośbach o łaskę przedstawiany był jako sprawiedliwy, wyrozumiały i litościwy „Pan życia i śmierci”.

List Tadeusza Gajdy „Tarzana” z prośbą o ułaskawienie był skierowany „Do Obywatela Prezydenta Krajowej Rady Narodowej w Warszawie ${ }^{\prime \prime 2}$. W lewym górnym rogu został opatrzony imieniem i nazwiskiem skazanego, natomiast nieco niżej intencją - prośbą o ułaskawienie. Tuż po wskazanym adresacie widnieje charakterystyczny zwrot pojawiający się w większości listów z prośbą o łaskę, który w przypadku „Tarzana” brzmi następująco: „Niżej podpisany skazany wyrokiem Rejonowego Sądu Wojskowego w Krakowie na sesji

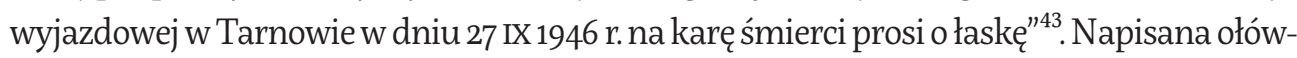
kiem, ładnym i czytelnym pismem prośba zajmuje dwie strony papieru kancelaryjnego. $\mathrm{Na}$ liście nie wpisano daty. Słowa nakreślone przez Gajdę wyrażały nadzieję, iż Prezydent KRN „usłyszy głos wołający o łaskę" ${ }^{\text {"44 } ~ „ O t w a r c i e ~ m ł o d z i e n ́ c z e j ~ d u s z y ~ i ~ s e r c a ~ p r z e d ~ O b y w a-~}$ telem Prezydentem" było próbą ukazania najistotniejszych chwil w życiu „Tarzana”. Zaczął przedstawiać je od etapu wstąpienia w szeregi AK, a następnie oddziału partyzanckiego. Gajda nie podał przy tym szczegółowych informacji odnoszących się do nazwy oddziału czy danych personalnych dowódców. Zaznaczył jednak, iż podczas okupacji niemieckiej brał udział w walkach razem z „partyzantami sowieckimi”. Mowa tu o bitwie na Porytowym Wzgórzu (14 czerwca 1944) stoczonej przez polskie i radzieckie oddziały partyzanckie z wojskiem niemieckim. Za zasługi i waleczność Armia Czerwona odznaczyła „Tarzana” medalem „Za Odwagę”. Prośba o ułaskawienie Gajdy wnosi do jego biografii ważną informację odnoszącą się do roli, jaką pełnił podczas walki w 1944 r. Autor napisał w niej, że wówczas jako szesnastolatek samodzielnie-z ręcznego karabinu maszynowegouratował życie 20 partyzantom radzieckim. Informacja ta zaskakuje, ponieważ patrząc na datę narodzin Gajdy i bitwy na Porytowym Wzgórzu, możemy stwierdzić, że „Tarzan” miał wtedy 20 lat.

40 AIPN Kr, sygn. 110/450/4, Wojskowy Sąd Rejonowy w Krakowie, 5 października1946, k. 193; tamże, Pismo Wojskowej Prokuratury Rejonowej w Krakowie, 8 listopada 1946, k. 221.

41 K. Szwagrzyk, Listy do Bieruta, s. 6.

42 AIPN Kr, sygn. 110/45o/4, Gajda Tadeusz. Prośba o ułaskawienie, k. 181.

43 Tamże.

44 T. Gajda słowa „dusza” w prośbie o ułaskawienie użył pięć razy. 
Kolejny element prośby o ułaskawienie Tadeusza Gajdy stanowi nakreślenie sytuacji „po oswobodzeniu terenów [...] przez Wojska Radzieckie”45. „Tarzan” podjęcie swoich decyzji określa mianem „rozdroża” i „walki”. Dzieje się tak za przyczyną wstąpienia mężczyzny w szeregi Ludowego Wojska Polskiego (LWP), w których jego przeszłość związana z działalnością w polskim państwie podziemnym była uznawana za powód do aresztowania. Gajda przed Bierutem przyznał się do dezercji, zaznaczając przy tym, że nie rozumiał postępowania nowo przyjętego porządku politycznego wobec żołnierzy walczących podczas okupacji niemieckiej.

Kolejny etap w życiu „Tarzana” związany był z działalnością w podziemiu antykomunistycznym, określoną przez skazanego charakterystycznymi zwrotami socjalistycznej wizji państwa. Gajda swoją walkę o suwerenność Ojczyzny nazwał mianem „rabunku” i „przestępczej działalności”, a ukrywanie się w lasach przed komunistycznym aparatem bezpieczeństwa porównał do losu „błędnego psa”. Młody mężczyzna w prośbie o ułaskawienie niejednokrotnie jako motywy swojego postępowania względem Ojczyzny przedstawiał chęć walki o niepodległość państwa polskiego i wolność narodu, a także wierność wyznawanym ideom.

Źródło, jakim w tym przypadku jest prośba o ułaskawienie, dostarcza fragmentarycznych wiadomości o życiu rodzinnym Gajdy. Z treści wynika, iż „Tarzan” był w związku

45 AIPN Kr, sygn. 110/450/4, Gajda Tadeusz. Prośba o ułaskawienie, k. 181.

46

Jozef Gajda ps. „Zawisza” - ojciec „Tarzana”, był zaangażowany w działalność konspiracyjną. Uczestnik walk w wojnie polsko-bolszewickiej, od 1940 r. należał do Now, gdzie zajmował się wywiadem. W 1945 r. wstąpił do oddziału swojego syna, pełniąc początkowo funkcję łącznika. „Zawisza” uczestniczył w wielu akcjach przeprowadzanych przez oddział „Tarzana”, a także pomagał w nawiązaniu kontaktów z członkami wiN powiatu brzeskiego. 8 sierpnia 1946 r.został aresztowany w Mielcu przez funkcjonariuszy UB, skąd przewieziono go do więzienie wUBP w Rzeszowie. Dzień wcześniej w Tarnowie aresztowano „Tarzana”. Wyrokiem wSR w Rzeszowie z 18 września 1946 r. "Zawisza” został skazany na karę śmierci. Wyrok wykonano 26 września 1946 r. poprzez rozstrzelanie. AIPN Rz, sygnn. 107/109, Akta śledcze p-ko Gajda Józef. Można jedynie domniemywać (ze względu na brak daty sporządzenia prośby o ułaskawienie przez „Tarzana”), iż Tadeusz nie wiedział o aresztowaniu swojego ojca, a także o wykonaniu wyroku na „Zawiszy”. małżeńskim, miał także dzieci. Ponadto przedstawione są marzenia 22-letniego mężczyzny - charakterystyczne dla człowieka, który dopiero zaczął wkraczać w dorosłość. Gajda pragnął wieść spokojne życie, które zostałoby przepełnione nie tyle ukrywaniem się w kompleksach leśnych, ile „uczciwą pracą" i „cichym ogniskiem domowym". Treść prośby o ułaskawienie nie zawierała żadnej wzmianki i danych personalnych odnoszących się do rodziców „Tarzana”. Nie można wykluczyć tego, iż Gajda celowo uniknął tego wątku w trosce o bezpieczeństwo najbliższych, których życie również było związane $\mathrm{z}$ podziemiem niepodległościowym ${ }^{46}$. 
List o ułaskawienie napisany przez Gajdę został zakończony prośbą „dwudziesto dwu letniej duszy i serca", do sedna której miał zajrzeć Bolesław Bierut przed wydaniem ostatecznego wyroku. Wobec „Tarzana” Prezydent KRN nie skorzystał z prawa łaski. 14 października 1946 r. w Centralnym Więzieniu Montelupich w Krakowie przy ul. Kamiennej 16 na Tadeuszu Gajdzie został wykonany wyrok śmierci - przez rozstrzelanie ${ }^{47}$. Na egzekucję „wychodził z celi spokojnie" ${ }^{48}$.

Wiesław Budzik „Roland” i Kazimierz Orczewski „Koziorożec”, którzy wraz z Gają zostali skazani na karę śmierci w tym samy procesie, również napisali prośby o ułaskawienie, kierując je do Prezydenta KRN w Warszawie ${ }^{49}$. Prośby opatrzone standardową formułą ${ }^{50}$ umieszczaną w tym samym miejscu pisma, zajęły objętość całej strony papieru kancelaryjnego. Orczewski, prosząc „gorąco o łaskę", wymienił cztery najważniejsze punkty: w pierwszym przyznał się do członkostwa w organizacji wiN, jednocześnie usprawiedliwiając swoją decyzję wstąpienia do organizacji niewiedzą i brakiem znajomości założeń organizacji. W bardzo podobny sposób prośbę o ułaskawienie zaczął Budzik, nazywając organizację NSZ „nielegalną”, a działalność w niej „rabunkiem”. „Roland” przyznał się do wykonania rozkazu wyroku śmierci, nie podając przy tym nazwiska osoby. Na podstawie jego wcześniejszych zeznań wiemy, iż w maju 1946 r. posądzony o współpracę z UB - Bronisław Dłużyński „Sęp” - został przez Budzika zastrzelony, a jego ciało wrzucono do Wisłoki ${ }^{51}$. W prośbie o ułaskawienie „Koziorożca” i „Rolanda” pojawiły się charakterystyczne wyrażenia socjalistycznej wizji państwa, które są celowym zabiegiem stosowanym przez skazanych. Budzik chciał zrekompensować swoją winę „solidną i wytrwałą pracą więźnia”, natomiast Orczewski pragnął „pracować dla ukochanej demokratycznej" Polski. Również w prośbie Gajdy pojawia się ten sam motyw - chęć posługi dla Ojczyzny, pisanej przez oskarżonych wielką literą, aby podkreślić jej wagę w życiu piszących. „Gorące prośby" i wiara w „litość Obywatela Prezydenta" nie przyniosły oczekiwanego rezultatu. Bierut nie skorzystał z prawa łaski wobec tarnowskich działaczy antykomunistycznych. Wiesław Budzik ps. „Roland” został stracony

47 AIPN Kr, sygn. 110/450/4, Protokół wykonania kary śmierci, 14 października X 1946, k. 199.

48 J. Lulek „Wichura”, „Na śmierć wychodził spokojnie”, S. 135 .

49 AIPN Kr, sygn. 110/450/4, Wiesław Budzik. Prośba o ułaskawienie, k. 179; tamże, Kazimierz Orczewski, Prośba o ułaskawienie, k. 180.

50 U Orczewskiego brzmi ona: „Niżej podpisany skazany wyrokiem Rejonowego Sądu Wojskowego w Krakowie na sesji wyjazdowej w Tarnowie w dniu 27 IX 1946 r. na karę śmierci prosi gorąco o łaskę motywując następująco [...]”, natomiast u Budzika: „Ja, niżej podpisany, skazany przez Wojskowy Sąd Rejonowy na sesji wyjazdowej w Tarnowie mocą wyroku z dnia 27 IX 1946 na karę śmierci, proszę o ułaskawienie".

51 AIPN Kr, sygn. 110/450/4, Protokół przesłuchania podejrzanego, 5 sierpnia 1946, k. 91. 
21 października 1946 r. $^{52}$, natomiast Kazimierz Orczewski „Koziorożec” 8 listopada $1946 \mathrm{roku}^{53}$.

Przedstawione prośby, mimo iż zachowały formalny charakter ${ }^{54}$, w rzeczywistości przybrały styl swobodny. Za przyczynę tego stanu można uznać nacechowany emocjonalnie, potoczny język, na podstawie którego możemy przyjąć, że „Tarzan”, „Budzik” i „Koziorożec” byli ludźmi, którzy w obliczu śmierci mieli nadzieję i marzenia. Prośby

52 AIPN Kr, sygn. 110/450/4, Protokół wykonania kary śmierci, 21 października 1946, k. 200.

53 AIPN Kr, sygn. 110/450/4, Protokół wykonania kary śmierci, 8 listopada 1946, k. 222.

54 Prośba zawiera: adresata i odbiorcę, dane dotyczące wymiaru kary i nazwy sądu wojskowego, który wydał orzeczenie o karze, datę i podpis. o ułaskawienie pisane przez trzech działaczy polskiego podziemia antykomunistycznego działających w Tarnowskiem mogą stać się z pewnością jednym ze źródeł do uzupełnienia biografii „Żołnierzy Wyklętych”. 


\section{Gajda Tadeusz}

prośba o ułaskawienie

\section{Do Obywatela Prezydenta Krajowej Rady Narodowej w Warszawie}

Niżej podpisany skazany wyrokiem Rejonowego Sądu Wojskowego w Krakowie na sesji wyjazdowej w Tarnowie w dniu 27 IX 1946 r. na karę śmierci prosi o łaskę.

Obywatelu Prezydencie to co będę pisał, będzie otwarciem mej młodzieńczej duszy i serca przed Obywatelem Prezydentem i prosiłbym bardzo, żeby przed wydaniem ostatecznego wyroku Obywatel Prezydent na chwilę był myślami razem ze mną i usłyszał głos wołający o łaskę mojej duszy.

Kiedy na ziemię naszą ojczystą stanęła stopa najeźdźcy hitlerowskiego pałając nieopisaną uczciwością od lat szkolnych poszedłem w szeregi Armii Krajowej, a następnie do oddziału partyzanckiego, gdzie ze czcią nosiłem karabin i strzelałem do śmiertelnego wroga. Tam uzyskałem medal Armii Radzieckiej za waleczność, ratując życie sam jeden z R.K.M. dwudziestu partyzantom sowieckim.

Miałem wtedy lat szesnaście i serce moje byłe przepełnione pełną radością, że mogę walczyć za Ojczyznę i naród. Kierunku politycznego żadnego nie miałem, a byłem tylko orlęciem którego dusza rwała się do walki przeciwko wrogowi.

Kiedy po oswobodzeniu terenów naszych przez Wojska Radzieckie odzyskaliśmy Ojczyznę, na ochotnika zgłosiłem się do wojska, aby dalej prowadzić rozpoczętą walkę zostawiając żonę i jedno dziecko. Tam jednak stanąłem na rozdrożu, bo kiedy władze Armii Radzieckiej dowiedziały się o tym, że byłem w partyzantce AK chciały mnie aresztować. Nie mogłem wtedy zrozumieć dlaczego wcześniej walczyłem, mam cierpieć teraz i mając żonę i dziecko, nie zdając sobie sprawy za namową kolegów uciekłem i miesiąc po tym zacząłem swą przestępczą działalność. Charakter mój był młody, bez żadnego doświadczenia życiowego i wtedy, kiedy toczyłem ze sobą walkę spotkałem swoich dowódców, którzy rzucili na rozognioną duszę moją ziarno zepsute wykorzystując moją łatwowierność i pchnęli mnie na drogę złą.

Obywatelu Prezydencie, to co robiłem to byłem przekonany wtedy, że robię dobrze, pracowałem jedynie dla idei. Do tego stopnia podziałała na mnie fałszywa propaganda moich przełożonych, że dopuściłem się kilku rabunków, idąc przekonany, że robię jedynie dla dobra Ojczyzny. Żona moja i dzieci moje niejednokrotnie pragnęli chleba, a ja ścigany przez władzę tułałem się po lasach jak błędny pies. Wreszcie przyszedł 
dzień opamiętania i od tego czasu przestałem swoją działalność, aż do chwili mojego aresztowania. Wycofać się zupełnie nie mogłem, ponieważ groziła mi zemsta ze strony moich przełożonych, ale jak mogłem tak słowem i czynem wprowadzałem swoich podwładnych na drogę uczciwości. Od chwili tej marzeniem moim było ciche ognisko domowe, gdzie bym mógł spokojnym życiem, uczciwą pracą przy żonie i małych dzieciach mógł pracować nad odbudową państwa Polskiego.

Obywatelu Prezydencie prosiłbym, aby przed wydaniem wyroku na mnie, zaglądnął do sedna mojej dwudziesto dwu letniej duszy i serca, zrozumiał mój wielki żal i błędy i to, że przecież żyjąc mogę przysłużyć się Ojczyźnie i państwu swą owocną pracą i wychować dzieci na dobrych synów demokratycznej Polski.

Gajda Tadeusz

Źródło: AIPN Kr, sygn. 110/45o/4, Gajda Tadeusz. Prośba o ułaskawienie, k. 181. 
Kraków, 28 Ix [rok nieczytelny]

\section{Do Obywatela Prezydenta K.R.N. w Warszawie}

Prośba o ułaskawienie

Ja, niżej podpisany, skazany przez Wojskowy Sąd Rejonowy na sesji wyjazdowej w Tarnowie mocą wyroku z dnia 27 IX 1946 na karę śmierci, proszę o ułaskawienie.

Wstępując do nielegalnej organizacji NSZ nie miałem pojęcia o jej nazwie, celach i środkach jakimi się posługują. W ciągu krótkiego czasu w którym byłem jej członkiem, zdołałem dowiedzieć się o tym, myśląc od tego czasu o wycofaniu. Lecz od razu zerwać nie było można, ponieważ czekała mnie kara i zemsta moich zwierzchników. W ciągu tego czasu popełniłem szereg rabunków, a nawet jedno zabójstwo popchnięty rozkazami. Wyrządziłem Ojczyźnie wielką krzywdę, którą pragnę naprawić solidną i wytrwałą pracą więźnia.

Obywatelu prezydencie. Wierzę, że Ojczyzna wybaczy mi to, że da mi możność naprawienia tych krzywd. Wierzę, że znajdę tyle litości w sercu Obywatela Prezydenta, aby ona wystarczyła na ułaskawienie.

Czekam z ufnością na miłosierdzie ukochanej Polski i Obywatela Prezydenta.

Budzik Wiesław

Źródło: AIPN Kr, sygn. 110/450/4, Wiesław Budzik. Prośba o ułaskawienie, k. 179. 


\section{Do Obywatela Prezydenta Krajowej Rady Narodowej w Warszawie}

\section{Orczewski Kazimierz}

Skazany wyrokiem na śmierć

Prośba o ułaskawienie

Niżej podpisany skazany wyrokiem Rejonowego Sądu Wojskowego w Krakowie na sesji wyjazdowej w Tarnowie w dniu 27 IX 1946 r. na karę śmierci prosi gorąco o łaskę motywując następująco:

1. Przyznałem do należenia do organizacji legalnej Win, do której zostałem wciągnięty nieświadomie nie znając ideologję a nawet [nieczytelne] gdybym wiedział, że wstępuję przeciw obecnemu ustrojowi, to niezgodziłbym gdyż byłem zawsze demokratą, a później było mi ciężko wycofać się.

2. Na każdym kroku uspokajałem społeczeństwo, aby Rządowi Jedności Narodowej nie przeszkadzała w budowie państwa Polskiego.

3. Nie występowałem nigdy z bronią przeciw społeczeństwu a jakoż pojedynczemu obywatelowi.

4. Nigdy nie należałem tak przed wojną, jak podczas okupacji niemieckiej do żadnej organizacji politycznej.

Prosiłbym gorąco Obywatela Prezydenta, aby pozwolił mi żyć i pracować dla ukochanej demokratycznej ojczyzny. Pozostawił przy życiu dla staruszków rodziców, którzy mieli mnie jednego. Rodzice powrócili w roku 1921 z Ameryki do ojczyzny aby żyć i pracować ze mną nad odbudową Polski a nawet będąc jeszcze w Ameryce dał na z budżetu pieniędzy dla Rosji Radzieckiej i Polski.

Orczewski Kazimierz

Źródło: AIPN Kr, syg̉n. 110/45o/4, Kazimierz Orczewski. Prośba o ułaskawienie, k. 180. 


\section{Bibliografia}

Archiwum Instytutu Pamięci Narodowej Oddział w Krakowie.

Archiwum Instytutu Pamięci Narodowej Oddział w Rzeszowie.

Ustawa dnia 3 lutego 2011 r. o ustanowieniu Narodowego Dnia Pamięci „Żołnierzy Wyklętych”, Dz.U. 2011 nr 32 poz. 160.

Bereza T., Program badawczy IPN „Osoby skazane na karę śmierci przez wojskowe sądy rejonowe w latach 1946-1955", w: Skazani na karę śmierci przez Wojskowy Sąd Rejonowy w Rzeszowie 1944-1954, red. T. Bereza, P. Chmielowiec, Rzeszów 2004.

Frazik W., Musiał F., Zabić Lwa, w: Precz z komuną. Z archiwów bezpieki - nieznane karty PRL, red. F. Musiał, J. Szarek, t. 3, Kraków 2006.

Zaplute karły reakcji. Polskie podziemie niepodległościowe 1944-1956, red. A. Jaczyńska, M. Śladecka, S. Poleszak, R. Wnuk, Lublin 2013.

Kucharski D. P., Wierni niepodległej, w: Do końca wierni. Żołnierze Wyklęci 1944-1963, red. D. P. Kucharski, R. Sierchuła, Poznań 2014.

Lulek J., „Wichura”, „Na śmierć wychodził spokojnie”. Wspomnienia z procesu BW WiN i PAS NZW w Tarnowie, oprac. M. Wenklar, „Zeszyty Historyczne WiN-u”, 30 (2009) s. 127-140.

Łabuszewski T., Bandy reakcyjnego podziemia czy zbrojne podziemie niepodległościowe, http:// klub-generalagrota.pl/kg/baza-wiedzy/referaty/639,Bandy-reakcyjnego-podziemia-czy-zbr ojne-podziemie-niepodleglosciowe.html, dostęp: 21.09.2016.

Łabuszewski T., Wstęp, w: Śladami zbrodni. Przewodnik po miejscach represji komunistycznych lat 1944-1956, red. T. Łabuszewski, Warszawa 2013.

Musiał F., Polityka czy sprawiedliwość? Wojskowy Sąd Rejonowy w Krakowie (1946-1955), Kraków 2005.

Musiał F., Skazani na karę śmierci przez Wojskowy Sąd Rejonowy w Krakowie 1946-1955, Kraków 2005.

Nowak S., Oddziały wyklętych, Warszawa 2014.

Solecki M., Literackie portrety żotnierzy wyklętych, Łomianki 2013.

Szwagrzyk K., Aparat bezpieczeństwa w latach 1944-1956, w: Aparat bezpieczeństwa w Polsce. Kadra Kierownicza 1944-1956, red. K. Szwagrzyk, t. 1, Warszawa 2005.

Szwagrzyk K., Listy do Bieruta. Prośby o ułaskawienie z lat 1946-1956, Wrocław 1995.

Szwedo B., „Tarzan” i jego żołnierze, „Tarnobrzeskie Zeszyty Historyczne”, 13 (1996), s. 3-50. Ślaski J., Żołnierze wyklęci, Warszawa 1996.

Żychowska M., Represje komunistyczne w Tarnowskiem 1945-1956, Kraków 2013. 